九州大学学術情報リポジトリ

Kyushu University Institutional Repository

\title{
Quantitative Detection of Cucumber Mosaic Cucumovirus RNA with Microplate Hybridization Using Digoxigenin-Labeled OLigo- Deoxyribonucleotide Probe
}

Uchiba, Takayuki

Laboratory of Plant Pathology, Graduate School of Bioresource and Bioenviromnental Sciences, Kyushu University

Takeshita, Minoru

Laboratory of Plant Pathology, Graduate School of Bioresource and Bioenviromnental Sciences, Kyushu University

Takanami, Yoichi

Laboratory of Plant Pathology, Graduate School of Bioresource and Bioenviromnental Sciences, Kyushu University

https://doi.org/10.5109/24279

出版情報 : 九州大学大学院農学研究院紀要. 43 (3/4)，pp. 343-348，1999-02. Kyushu University バージョン：

権利関係: 


\title{
Quantitative Detection of Cucumber Mosaic Cucumovirus RNA with Microplate Hybridization Using Digoxigenin-Labeled Oligo-Deoxyribonucleotide Probe
}

\author{
Takayuki Uchiba, Minoru Takeshita, and Yoichi Takanami \\ Laboratory of Plant Pathology, Graduate School of Bioresource and \\ Bioenvironmental Sciences, Kyushu University, Hakozaki, \\ Higashi-k11, Fukuoka 812-8581, Japan \\ (Received October 29, 1998 and accepted November 6, 1998)
}

\begin{abstract}
A simple microplate hybridization method was developed for subgroup-specific and quantitative detection of RNA of cucumber mosaic cucumovirus (CMV). Digoxigenin (DIG) -labeled, synthetic oligo-deoxyribonucleotides were used as the probes for hybridization. CMV RNAs were adsorbed to microplate wells and then hybridized with the probes specific for the respective subgroups of CMV. Under optimal conditions, about one ng of CMV RNA was detected withont any nonspecific reactions. When total RNAs extracted from tobacco plants infected with $\mathrm{CMV}-\mathrm{Y}, \mathrm{CMV}-\mathrm{m} 2$ or mock-inoculated were subjected to the hybridization, we found so cross-reactions between viral RNAs of subgroup I and It and no nomspecific reactions against healthy controls. The microplate hybridization method had several advantages over conventional dot blot hybridization methods.
\end{abstract}

\section{INTRODUCTION}

Cucumber mosaic cucumovirus (CMV) is a small spherical plant virus and is the type member of Cucumovirus in the family of Bromoviridae. CMV has a tripartite RNA genome consisting of RNA1, RNA2, and RNA3 (Peden and Symons, 1973); a subgenomic coat protein messenger RNA (RNA4) is generated during replication of RNA3 (Schwinghamer and Symons, 1974). CMV is divided into subgroup I and II based on serological property and differences in nucleotide sequences (Palukaitis et al., 1992). We are now investigating the molecular basis of a phenomenon in plant virus infection, known as cross-protection, using various CMV strains. In the course of this study, we need to develop methods that could discriminate subgroup I and II of CMV RNAs in doubly infected cells or leaf tissues. We have already developed a method to specifically detect CMV strains belonging to the respective subgroups with dot blot and northern blot hybridization using digoxigenin(DIG)-labeled synthetic oligo-deoxyribonucleotide probes (Takanami et al., 1999).

Inouye and Hondo (1990) developed a new hybridization method for detection of varicella-zoster virus by directly adsorbing PCR-amplified viral DNA fragments onto polystylene microplate wells. Thereafter, a number of reports describing the "microplate hybridization" method have accumulated and availability of the method has been confirmed (Ruiz et al., 1995). Almost all of these procedures contained the use of PCR -amplified cDNA as targets. In this study, a microplate hybridization technique was developed for subgroup-specific detection of CMV RNAs using DIG-labeled, synthetic oligo-deoxyribonucleotide probes complementary to the specific regions in the viral 
genome RNAs of the respective subgroups. The immobilized RNA was hybridized with the probes, then the hybridization signal was detected by alkaline phosphatase-con -jugated antibody, as in an enzyme-linked immunosorbent assay (ELISA).

\section{MATERIALS AND METHODS}

\section{Viruses and genomic RNA extraction}

CMV-Y (Tomaru and Hidaka, 1960) belonging to subgroup I and CMV-ni2 (Takanami et al., 1998) belonging to subgroup II were maintained in Nicotiana tabacum L. cv. Xanthi-nc in a greerhouse. Virus was purified as described before (Takanami, 1981). Viral RNA was extracted as follows. Purified virus was incubated at $50^{\circ} \mathrm{C}$ for $5 \mathrm{~min}$ in $10 \mathrm{mM}$ Tris-HCl, pH 8.0, $1 \mathrm{mM}$ EDTA, $1 \%$ sodium dodecyl sulfate (SDS), then RNA was extracted with an equal volume of phenol: chloroform ( $1: 1)$ mixture, and precipitated with 2.5 volumes of ethanol. Total RNA in the infected tobacco leaves werc extracted according to Takeshita et al. (1998).

\section{DIG-labeled probes}

DIG-labeled oligo-deoxyribonucleotide probes $\mathrm{Y}-2$ and $\mathrm{m} 2-2$ were complementary to the 3' non-translated regions of CMV-Y (RNA3 : 2132-2175 nt) and CMV-m2 (RNA3: $2113-2157 \mathrm{nt}$ ), respectively. The details of the probes will be described elsewhere (Takanami et al., 1999)

\section{Microplate hybridization}

Hybridization was carried out as follows. The purified CMV RNA was diluted in $0.2 \mathrm{ml}$ of $10 \mathrm{mM}$ sodium phosphate, $\mathrm{pH} 7.0$, and $10 \mathrm{mM}$ EITA, containing various concentrations of $\mathrm{NaCl}$ and added to the each well of microtiter plate for immunosorbent assay (Nunc-immuno plate). After incubated at $37^{\circ} \mathrm{C}$ for $2 \mathrm{hr}$, the wells were rinsed once with phosphate-buffered saline containing $0.1 \%$ Tween 20 (PBST). Then $0.1 \mathrm{ml}$ solutions containing the probes $(20 \mathrm{ng} / \mathrm{ml}), 50 \%$ formanide, $0.75 \mathrm{M} \mathrm{NaCl}, 5 \mathrm{mM}$ sodium phosphate, pH 7.0, $0.1 \mathrm{mg}$ of total yeast RNA, $0.1 \%$ Tween 20 , and $5 \mathrm{mM}$ EDTA were added. The microplate was incubated in a hybridization oven at various temperatures as mentioned below for more than $16 \mathrm{hr}$. After the wells were rinsed three times with PBST, $0.1 \mathrm{ml}$ of alkaline-phosphatase-conjugated anti-DIG- $\gamma$-globulin, Fab fragment (Boehringer Manheim), that was diluted to $1: 5000$ in PBST was added. After incubated at $37^{\circ} \mathrm{C}$ for $3 \mathrm{hr}$, the wells were rinsed with PBST three times. For each well, $0.1 \mathrm{ml}$ of $1 \mathrm{mg} / \mathrm{ml}$ $p$-nitrophenyl-azo-phosphate diluted in diethanol amine, $\mathrm{pH} 9.8$, was added. The plate was sealed, and then incubated at $37^{\circ} \mathrm{C}$ for $2 \mathrm{hr}$. Absorbance at $405 \mathrm{~nm}$ of each well was determined with a microplate reader every thirty minutes after incubation.

\section{RESULTS}

\section{Optimum NaCl concentration for adsorption of CMV RNA to microplate wells}

To determine the optimum concentration of $\mathrm{NaCl}$ for immobilizing CMV RNA to the well, fixation step was carried out at various $\mathrm{NaCl}$ concentrations. In this experiment, each well contained $10 \mathrm{ng}$ of $\mathrm{CMV}-\mathrm{Y}$ or $\mathrm{CMV}-\mathrm{m} 2 \mathrm{RNA}$, and the RNA was hybridized with 
probe $\mathrm{Y}-2$ or $\mathrm{m} 2-2$. As shown in Table 1 , fixation at $2.5 \mathrm{M} \mathrm{NaCl}$ gave the highest hybridization signals. Potassium chloride or ammonium sulfate could also be used to fix CMV RNA (data not shown).

Table 1. Effect of various $\mathrm{NaCl}$ concentrations on inunobilization of CMV RN $\Lambda$ to microplate.

\begin{tabular}{ccc}
\hline \multirow{2}{*}{$\mathrm{NaCl}$ concentrations } & \multicolumn{2}{c}{ Probe/Sample RNA } \\
\cline { 2 - 3 } & $\mathrm{Y}-2 / \mathrm{CMV}-\mathrm{Y}$ & $\mathrm{m} 2-2 / \mathrm{CMV}-\mathrm{m} 2$ \\
\hline $1.0 \mathrm{M}$ & 0.021 & 0.027 \\
$1.5 \mathrm{M}$ & 0.172 & 0.103 \\
$2.0 \mathrm{M}$ & 0.241 & 0.126 \\
$2.5 \mathrm{M}$ & 0.261 & 0.190 \\
$3.0 \mathrm{M}$ & 0.144 & 0.160 \\
\hline
\end{tabular}

Absorbance at $405 \mathrm{~nm}$ was measured after colorimetric. reaction for $2 \mathrm{hr}$. Each well contains $10 \mathrm{ng}$ of CMV RNA.

\section{Hybridization temperature}

To determine the optimum temperature for the hybridization reaction between target RNAs and the DIG probes, hybridization was carried out at different temperatures. In this experiment, each well contained $100 \mathrm{ng}$ of $\mathrm{CMV}-\mathrm{Y}$ or CMV-m2 RNA. Both probes $\mathrm{Y}-2$ and $\mathrm{m} 2-2$ gave the highest values of absorbance when hybridization was carried out at $45^{\circ} \mathrm{C}$ (Table 2). The sensitivity of probe $\mathrm{m} 2-2$ was lower at higher or lower temperature than at $45^{\circ} \mathrm{C}$ compared with that of probe $\mathrm{Y}-2$.

Table 2. Optimum hybridization temperature for detection of CMV RNA.

\begin{tabular}{ccc}
\hline \multirow{2}{*}{$\begin{array}{c}\text { Hybridization } \\
\text { temperatures }\end{array}$} & \multicolumn{2}{c}{ Probe / Sample RNA } \\
\cline { 2 - 3 } & $\mathrm{Y}-2 / \mathrm{CMV}-\mathrm{Y}$ & $\mathrm{m} 2-2 / \mathrm{CMV}-\mathrm{m} 2$ \\
\hline \multirow{2}{*}{$43^{\circ} \mathrm{C}$} & 0.846 & 0.696 \\
$45^{\circ} \mathrm{C}$ & 1.663 & 1.634 \\
$47^{\circ} \mathrm{C}$ & 1.649 & 0.720 \\
\hline
\end{tabular}

Absorbance at $405 \mathrm{~nm}$ was measured after colorimetric reaction for $2 \mathrm{hr}$. Each well contains $100 \mathrm{ng}$ of CMV RNA.

\section{Sensitivity of microplate hybridization}

To know the detection limit of CMV RNA with microplate hybridization, CMV RNA was serially twofold diluted and adsorbed to the microplate. Adsorption of CMV RNA and hybridization reaction were performed at the optimum conditions described above. About 1 ng of CMV RNA could be detected, and probes Y-2 and m2-2 showed almost equal sensitivity to the RNAs of the respective CMV strains (Fig. 1). 


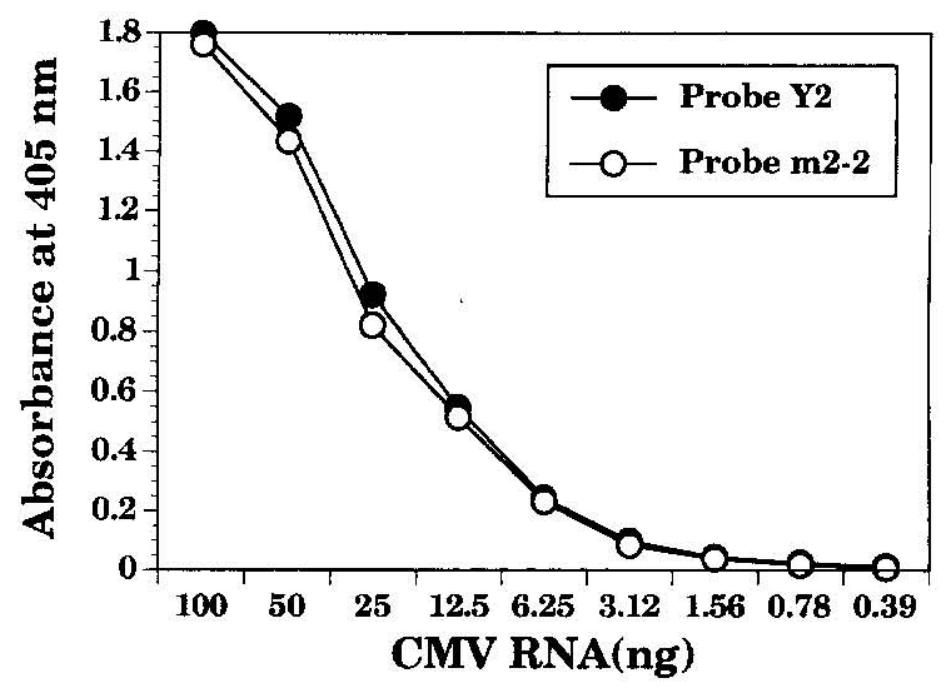

Fig. 1. Sersitivity of the microplate hybridization method for detection of CMV RNA. Purified genomic RNA of CMV-Y or CMV-ri2 was serially diluted in 2-fold steps from $100 \mathrm{ng}$ to about $0.39 \mathrm{ng} / 0.2 \mathrm{ml}$. RNA was adsorbed to microplate wells, and hybridization was carried out using the DIG-labeled probe. Absorbance values were measured after colorimetric reaction for 2 hr.

\section{Specificity of microplate hybridization}

RNAs of CMV-Y and CMV-m2 were immobilized in wells of microplate (100 ng/well) and the hybridization reactions were carried out using the both probes.

As shown in Table 3, the both probes hybridized only with the RNA of the respective CMV strains. Furthermore, when total RNAs extracted from tobacco plants infected with CMV-Y, CMV-m2 or mock-inoculation were subjected to the hybridization, we found no cross-reactions between viral RNAs of subgroup I and II and no nonspecific reactions against healthy controls.

Table 3. Subgroup specific detection of CMV RNA.

\begin{tabular}{ccccccc}
\hline \multirow{2}{*}{ Probes } & \multicolumn{2}{c}{ Purified CMV RNA } & & \multicolumn{3}{c}{ Total RNA from tobacco leaves } \\
\cline { 2 - 3 } \cline { 5 - 7 } & $\mathrm{Y}$ & $\mathrm{m} 2$ & & $\mathrm{H}^{\mathrm{n}}$ & $\mathrm{Y}^{\mathrm{n}}$ & $\mathrm{m}^{\mathrm{l}}$ \\
\hline $\mathrm{Y}-2$ & 1.673 & 0.004 & & 0.001 & 0.445 & 0.000 \\
$\mathrm{~m} 2-2$ & 0.005 & 1.644 & & 0.000 & 0.000 & 0.525 \\
\hline
\end{tabular}

Absorbance at $405 \mathrm{~nm}$ was measured after colorimetric reaction for $2 \mathrm{hr}$. Purified CMV RNA (100ng each) or total RNAs (extracted from about $1.25 \mathrm{mg}$ of infected tobacco leaf) were adsorbed. a): Total RNA were extracted from healthy tobacco leaf. b): Total RNA were extracted from tobacco leaves infected with $C M V-Y$ or $\mathrm{CMV}-\mathrm{m}^{2}$. 


\section{DISCUSSION}

The microplate hybridization method described here has several advantages over conventional dot blot methods. First, the microplate can be handled much more easily than the dot blot membrane. For instance, washing of the microplate solid phase is more rapid, as it is in the ELISA. Furthermore, blocking procedures that are indispensable for dot blot hybridization on membranes were not required. Second, a specific RNA can be detect not only qualitatively but also quantitatively by reading the optical absorbance values using an automated microplate reader.

Generally, hybridization reaction between probes and target nucleic acid is considered to be enhanced at lower hybridization temperature though nonspeciic hybridization would increase. Our data concerning the optimal hybridization temperature, however, were not the case. We speculate that the target RNA adsorbed to microplate at only one end ( 3 ' or $\left.5^{\prime}\right)$ of the strand might form secondary and/or tertiary structures more easily at lower temperature so that hybridization between RNA and probes would be inhibited. It is well known that the 3'-noncoding regions of CMV RNA where the target sequences of the probes were present can form tRNA-like structure (Wilson et al., 1981; Joshi et al, 1983).

\section{ACKNOWLEDGEMENT}

This work was partly supported by Grant-in-Aid for Scientific Research (A) 08406004 from The Ministry of Education, Science, Sports and Calture, Japan

\section{REFERENCES}

Inouyc: S. and R. Hondo 1990 Microplate hybridization of amplified viral IDNA segment. J. Clinic. Microbiol., 28: 1469-1472

Joshi, RL., S. Joshi, F. Chapeville, and AL. Haenni 1983 tRNA-ike structures of plants viral RNAs: conformational requirements for adenylation and aminoacylation. EMBO J., 2: 1123-1127

Palukaitis, P., M. J. Roossinck, R. G. Dietzgen, and R. I. B. Francki 1992 Cucumber mosaic virus. Adv. Virnus Res., 41: 281-348

Peden, K. W. C. and R. H. Synons 1973 Cucumber mosaic virus contains a functionally divided genome. Virology, 53: $487-492$

Ruiz, B. H., M. P. Zamora, and S. Liu 1995 Detection of dengue viral RNA by microplate hybridization. $J$. Virol. Methods, 54: $97-108$

Schwinghamer, M. W. and R. H. Symons 1977 Translation of the four major RNA species of cucumber virus in plant and animal cell-free systems and in toad oocytes. Virology, 79: 88-108

Takanami, Y. 1981 A striking change in symptoms on cucumber mosaic virus-infected tobacco plants induced by a satellite RNA. Virology, 109: 120126

Takanami, Y., T. Uchiba, T. Shigemi, K. Kikuhara, and M. Takeshita 1999 Specific detection of subgroup I and II of cucumber mosaic virus RNA with digoxigenin-labeled synthetic deoxyribonucleotide probes. Ann. Phytopathol. Soc. Jpn., 65: (in press)

Takanami Y., K. Kikuhara and M. Takeshita 1998 Two isolates of cucumber mosaic cucumovirus expressing mild mosaic symptoms on tobacco plants. J. Fac. Agric. Kyushu, univ., 43: (in press)

Takeshita, M., M. Suzuki, S. Kuwata and Y. Takanami 1998 Involvement of cucumber mosaic cucumovirus RNA2 and RNA3 in viral systemic spread in radish plant. Arch. Virol., 143: 1109-1117

Tomaru, K. and Z. Hidaka 1960 Strains of cucumber mosaic virus isolated from tobacco plants. II. A yellow strain. Bull. Ilatano Tob. Exp. Sta., 46: 143-149 
Wilson, P. A. and R. H. Symons 1981 The liNAs of cucumoviruses: 3'-terminal sequence analysis of two strains of tomato aspermy virus. Virology, 112: $342-345$ 